\title{
PENGARUH FAKTOR DEMOGRAFI DAN FAKTOR PSIKOLOGI INVESTOR DALAM PENGAMBILAN KEPUTUSAN INVESTASI DI ERA EKONOMI DIGITAL
}

\author{
Asri Nur Wahyuni ${ }^{1}$ Nugroho Heri Pramono $^{2}$ \\ STIE Bank BPD Jateng \\ asri.nur.wahyuni@gmail.com
}

\begin{abstract}
All forms of convenience in the digital economy era attract potential investors to invest, one of which is the existence of financial technology (fintech). On the other hand, technological advances have also made it easier for companies and governments to market their products and raise funds from the public. There are demographic and psychological factors in making investment decisions, especially in the digital economy era. Demographic factors reflect the characteristics of investors that are often a concern in influencing investment decisions. In addition, there are psychological factors that can also influence an investor when making investment decisions. The purpose of this study is to determine the influence of demographic factors and psychological factors of an investor in choosing investment instruments in the era of the digital economy. This study uses primary data by distributing questionnaires to respondents using google form. The analysis used in this study used descriptive analysis, frequency analysis, Crosstab - Chi Square test and hypothesis testing. Age and education as demographic factors have an influence on investment decisions. Demographic factors such as gender, marital status and employment do not have an influence on investment decisions. Other results in this study indicate that psychological factors consisting of overconfidence, data mining, social interaction, emotion and considering the past have an effect on investment decisions. Demographic factors with psychological factors in this study together have an influence on investment decisions.
\end{abstract}

Keywords: demographic factors; psychological factors; investation decision

\begin{abstract}
Abstrak
Segala bentuk kemudahan di era ekonomi digital menjadi daya tarik bagi para calon investor untuk berinvestasi salah satunya adalah keberadaan teknologi finansial (fintech). Di sisi lain, kemajuan tekhnologi juga memudahkan perusahaan dan pemerintah untuk memasarkan produknya dan pencarian dana dari masyarakat. Terdapat faktor demografi dan faktor psikologis dalam melakukan pengambilan keputusan investasi terutama di era ekonomi digital. Faktor demografi sebagai cerminan dari karakteristik investor yang sering menjadi
\end{abstract}

* Corresponding author's e-mail: asri.nur.wahyuni@gmail.com

http://openjournal.unpam.ac.id/index.php/JABI 
perhatian dalam mempengaruhi keputusan investasi. Selain itu ada faktor psikologis yang juga dapat mempengaruhi seorang investor saat mengambil keputusan investasi. Tujuan penelitian ini untuk mengetahui pengaruh faktor demografi dan faktor psikologis seorang investor dalam memilih instrumen investasi di era ekonomi digital. Penelitian ini menggunakan data primer dengan menyebarkan kuesioner kepada responden menggunakan google form. Analisis yang digunakan dalam penelitian ini menggunakan analisis deskriptif, analisis frekuensi, Crosstab - Uji Chi Square dan uji hipotesis. Usia dan pendidikan sebagai faktor demografi memiliki pengaruh terhadap keputusan investasi. Faktor demografi berupa jenis kelamin, status pernikahan dan pekerjaan tidak memiliki pengaruh pada keputusan investasi. Hasil lainnya dalam penelitian ini menunjukkan bahwa faktor psikologi yang terdiri dari overconfidence, data mining, social interaction, emotion dan considering the past berpengaruh terhadap keputusan investasi. Faktor demografi dengan faktor psikologis dalam penelitian ini secara bersama - sama memiliki pengaruh terhadap keputusan investasi.

\section{Kata Kunci : faktor demografi; faktor psikologis; keputusan investasi}

\section{PENDAHULUAN}

Di era industri 4.0 perkembangan teknologi juga terjadi di lingkungan pasar modal. Dampak yang terasa adalah semakin mudahnya para calon investor baru untuk melakukan investasi di pasar modal Indonesia. Segala bentuk kemudahan di era ekonomi digital ini menjadi daya tarik tersendiri bagi para calon investor untuk berinvestasi salah satunya adalah keberadaan teknologi finansial (fintech). Di sisi lain, kemajuan tekhnologi juga memudahkan perusahaan dan pemerintah untuk memasarkan produknya dan pencarian dana dari masyarakat.

Indonesia merupakan salah satu negara dengan penduduk yang selalu memanfaatkan perkembangan tekhnologi dalam kehidupannya. Hal ini pula yang menjadikan masyarakat Indonesia mulai memikirkan mengenai kebutuhan investasi. Peningkatan jumlah investor di pasar modal Indonesia semakin bertambah setiap tahunnya. Hal ini dapat dilihat pada gambar 1 dibawah ini:

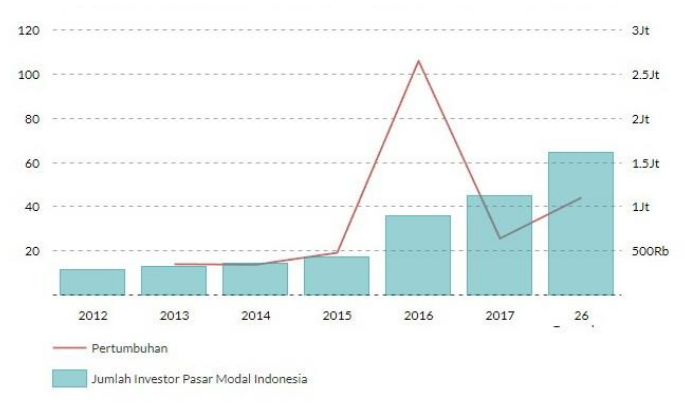

Sumber : PT. Kustodian Sentral Efek Indonesia (KSEI)

\section{Gambar 1. Jumlah Investor Pasar Modal Indonesia 2012 - 2018}

* Corresponding author's e-mail: asri.nur.wahyuni@gmail.com

http://openjournal.unpam.ac.id/index.php/JABI 
Single Investor Identification (SID) yang tercatat pada KSEI sebagai acuan untuk mengetahui jumlah investor di pasar modal Indonesia terus mengalami peningkatan. Gambar 1 di atas menunjukkan bahwa jumlah investor pada tahun 2018 meningkat secara signifikan dibandingkan pada tahun 2017 yang terlihat pertumbuhannya sebesar $44,06 \%$ dengan jumlah investor 1,6 juta investor. Secara statistik terlihat bahwa pada tahun 2017 jumlah investor pasar modal Indonesia mencapai $25,56 \%$ dari total investor pasar modal di Indonesia yang berjumlah 1,1 juta investor. Pada tahun 2016 pertumbuhan jumlah investor di pasar modal Indonesia bahkan mencapai 105,97\% dengan jumlah investor sebanyak 894.100 investor.

Instrumen investasi yang tersedia pun semakin beragam. Jenis intrumen investasi dari yang real investment hingga yang berbentuk financial instrument dapat menjadi pilihan bagi para investor dalam berinvestasi. Keunggulan dan kelemahan yang terkandung dalam masing - masing bentuk instrumen investasi menjadi pertimbangan tersendiri bagi para investor. Faktor lain yang akan berpengaruh pada pengambilan keputusan investasi bagi seorang investor adalah faktor demografi sebagai faktor yang melekat pada setiap individu investor yang akan berpengaruh pada saat keputusan investasi diambil. Faktor demografi sebagai cerminan dari karakteristik investor yang sering menjadi perhatian dalam mempengaruhi keputusan investasi adalah jenis kelamin, usia, tingkat pendidikan, pekerjaan dan status pernikahan.

Seorang investor dalam melakukan pengambilan keputusan juga tidak lepas dari pengaruh oleh faktor psikologis. Hal ini dikarenakan pengambilan keputusan terkait investasi adalah sebuah pengambilan keputusan yang mengandung risiko. Investasi akan selalu mengandung unsur ketidakpastian yang menjadikan risiko akan selalu melekat di dalamnya. Faktor psikologis yang sering mempengaruhi seorang investor adalah overconfidence, data mining, social interaction, emotion dan considering the past. Di pasar modal Indonesia, jumlah investor individu mencapai 1,6 juta jiwa atau $0,38 \%$ dari 260 juta jiwa penduduk Indonesia secara keseluruhan. Meskipun demikian, jumlah investor individu di Indonesia masih di bawah negara Singapura yang memiliki 2,5 juta jiwa investor dan negara Malaysia sebanyak 2,49 juta jiwa investor pada tahun 2018. Berbagai macam latar belakang investor individu yang ada di Indonesia menjadi investment habit yang berbeda dalam memilih instrumen investasi yang tersedia.

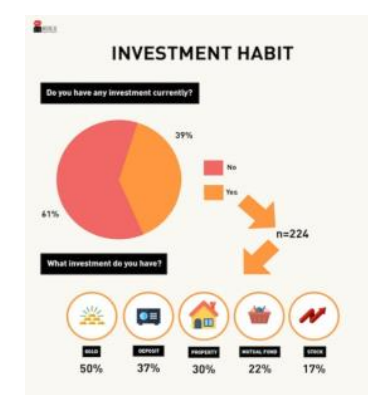

Sumber : Kontan.co.id.,2018

\section{Gambar 2. Investment Habit}

* Corresponding author's e-mail: asri.nur.wahyuni@gmail.com

http://openjournal.unpam.ac.id/index.php/JABI 
Berdasarkan temuan Inside ID dalam Kontan.co.id. (2018), dari 600 konsumen yang disurvei secara online, hanya 13\% yang mengalokasikan pendapatannya untuk tabungan dan investasi.dari total seluruh responden diketahui sebanyak 39\% responden yang memiliki kelebihan dana dan mereka akan menginvestasikan dananya dalam instrumen investasi yang ada. Hasil riset tersebut juga menunjukkan bahwa emas merupakan instrumen investasi yang menjadi primadona bagi orang Indonesia. Setengah dari $39 \%$ responden yang memiliki kelebihan dana memilih untuk berinvestasi di logam mulia. Investasi lainnya yang menjadi pilihan secara berturut-turut yaitu deposito (37\%), properti (30\%), reksadana (22\%), dan saham (17\%). Hal ini menunjukkan bahwa banyak investor di Indonesia yang memilih instrumen logam mulia (emas) sebagai pilihan karena dianggap instrumen ini memiliki risiko yang kecil.

Permasalahan penelitian ini adalah terdapat faktor demografi dan faktor psikologis yang berpengaruh saat investor mengambil keputusan investasi terutama di era ekonomi digital. Faktor demografi sebagai cerminan dari karakteristik investor yang sering menjadi perhatian dalam mempengaruhi keputusan investasi. Selain itu ada faktor psikologis yang juga dapat mempengaruhi seorang investor saat mengambil keputusan investasi. Penelitian ini memiliki tujuan untuk mengetahui seberapa besar pengaruh dari faktor demografi dan faktor psikologis seorang investor saat mengambil keputusan investasi di era ekonomi digital. Penelitian ini memberikan rekomendasi untuk para komunitas investasi, akademis dan penelitian lainnya.

\section{KERANGKA TEORITIS DAN PENGEMBANGAN HIPOTESIS}

\section{Faktor Demografi}

Faktor demografi perlu dipertimbangkan dalam mengambil keputusan investasi karena memiliki pengaruh terhadap investor. Beberapa faktor demografi yang digunakan adalah:

1) Jenis Kelamin

Jenis kelamin diartikan sebagai perbedaan biologis pada manusia yang dikenal dengan pria dan wanita. Didalam aspek ekonomi, pria dan wanita mempunyai perbedaan dalam pengambialn keputusan (Rizkiana \& Kartini, 2017). Pada umumnya, seorang investor pria cenderung akan menempatkan dananya di pasar modal dengan asset yang memiliki risiko tinggi sedangkan seorang investor wanita akan lebih memilih industri perbankan dengan risiko yang lebih rendah (Lutfi, 2010). Hasil yang sama diperoleh pada penelitian Andrew \& Linawati (2014) dan Loke (2017), Jain \& Mandot (2012) serta Jamil \& Khan (2016).

2) Usia

Usia merupakan batasan atau tingkat ukuran hidup yang mempengaruhi kondisi fisik seseorang. Semakin tua usia seseorang, akan semakin menghindari risiko dalam pengambilan keputusan berinvestasi, begitu pula sebaliknya. Hal ini terjadi karena seiring bertambahnya usia, pengetahuan dan pegalaman yang cukup telah dimiliki oleh seseorang saat mengambil

* Corresponding author's e-mail: asri.nur.wahyuni@gmail.com

http://openjournal.unpam.ac.id/index.php/JABI 
keputusan. Hasil penelitian Christanti dan Mahastanti (2011) menunjukkan bahwa seorang investor yang usianya matang lebih banyak mengambil keputusan investasi berdasarkan pada logika.

3) Tingkat Pendidikan

Tingkat pendidikan seseorang akan menunjukkan tingkat penguasaan ilmu pengetahuan yang dimiliki orang tersebut dalam memahami suatu hal dengan baik khususnya di bidang akademik. Toleransi seorang investor terhadap risiko juga dapat dipengaruhi oleh tingkat pendidikan. Semakin tinggi tingkat pendidikan seseorang maka semakin tinggi pula tingkat toleransi orang tersebut atas risiko yang dihadapi (Bhandari \& Deaves, 2006). Investor yang menempuh pendidikan paling tidak diploma, akan lebih memilih untuk menginvestasikan dananya pada pasar modal dibandingkan berinvestasi pada produk bank atau asset riil (Lutfi, 2010). Hal ini dikarenakan tingkat pendidikan yang tinggi dianggap memiliki pengetahuan dan kemampuan yang sangat baik dalam berinvestasi sehingga mampu menganalisis dan memperhitungkan risiko yang dihadapi. Hasil yang sama juga diperoleh pada penelitian Jamshidinavid et al (2012) dan Lin (2011).

4) Pekerjaan

Pekerjaan merupakan profesi yang disandang seseorang dalam melakukan aktivitas yang memberikan hasil baik berupa pengalaman atau materi yang dapat menunjang kehidupannya. Terdapat keterkaitan antara pekerjaan dengan penghasilan di mana semakin baik pekerjaan yang diselesaikan maka penghasilan yang akan diperoleh pun akan semakin besar.

5) Status Pernikahan

Status pernikahan adalah gelar non - akademis yang disandang oleh orang yang sudah dewasa dan mampu menanggung hidupnya bersama orang lain. Investor yang belum menikah cenderung menanamkan dananya pada asset yang lebih berisiko dibandingkan investor yang sudah menikah (Lutfi,2010). Hal ini menjelaskan bahwa seseorang yang sudah menikah merupakan tipe investor yang menghindari risiko (risk averter) karena mereka akan lebih mengutamakan pemenuhan kebutuhan rumah tangganya terlebih dahulu sebelum melakukan investasi.

\section{Faktor Psikologis}

Pada penelitian sebelumnya menunjukkan hasil yang berbeda mengenai pengaruh dari faktor psikologis atas toleransi seorang investor terhadap risiko yang dihadapi pada saat memutuskan untuk berinvestasi.

1) Overconfidence digambarkan sebagai sifat yang terlalu percaya diri. Hampir seluruh temuan hasil penelitian atas faktor psikologis menyimpulkan bahwa perilaku overconfidence cenderung mendorong pengambil keputusan untuk menentukan prediksi yang tidak akurat sehingga menghasilkan kesalahan prediksi yang lebih tinggi dibandingkan yang bersikap rasional. Menurut Nosfinger (2010), seorang investor pria pada umumnya lebih percaya diri daripada seorang investor wanita. Hasil yang sama juga ditunjukan pada penelitian Jain dan Mandot (2012).

* Corresponding author's e-mail: asri.nur.wahyuni@gmail.com

http://openjournal.unpam.ac.id/index.php/JABI 
2) Data mining adalah proses penggalian data yang sebelumnya tidak diketahui, informasi yang valid dan ditindaklanjuti dari database yang besar dan kemudian menggunakan informasi tersebut untuk membuat keputusan bisnis penting (Gatnar dkk, 2005).

3) Social interaction merupakan gambaran orang-orang dalam berkomunikasi dan berbagi informasi terkait investasi. Interaksi dan pendapat orang lain dapat berpengaruh pada keputusan seseorang saat melakukan investasi (Nofsinger, 2010).

4) Emotion akan berpengaruh terhadap keputusan investasi. Semakin kompleks dan adanya ketidakpastian dari satu situasi, emosi akan semakin mempengaruhi keputusan untuk berinvestasi (Nosfinger, 2010).

5) Considering the past menjadikan kejadian di masa lalu sebagai dasar evaluasi untuk menentukan apakah situasi yang dialami di masa lalu diinginkan kembali atau dihindari di masa depan (Nosfinger, 2010).

\section{Keputusan Investasi}

Menurut Halim (2015) investasi pada hakekatnya merupakan penempatan sejumlah dana pada saat ini dengan harapan untuk memperoleh keuntungan di masa mendatang. Keputusan investasi merupakan kegiatan yang dilakukan seseorang yang memiliki kelebihan dana. Seorang investor akan selalu berhati - hati sebelum melakukan pengambilan keputusan investasi. Sebuah investasi akan selalu mengandung dua unsur utama yang menjadi pertimbangan bagi seorang investor yaitu besarnya return yang akan diperoleh dan besarnya risk yang harus ditanggung. Semakin besar return yang akan diperoleh maka semakin tinggi pula risk yang akan ditanggung. Demi mengurangi tingkat risk yang harus ditanggung, maka seorang investor biasanya akan mendiversifikasi dananya ke dalam berbagai macam instrument investasi yang ada.

4. Hubungan Faktor Demografi Terhadap Keputusan Investasi

Kondisi sosial ekonomi dan demografi berpengaruh signifikan terhadap minat investasi seseorang (Widayat, 2010). Hasil yang sama diperoleh pada penelitian Artina dan Idham (2018), Iswantoro dan Anastasia (2013), Harli dkk (2015), Arafia (2011), Pradhan \& Kasilingam (2015).

Meskipun demikian hasil yang berbeda diperoleh pada penelitian yang dilakukan Utami dan Kartini (2016) yaitu faktor demografi (usia, jenis kelamin, pendidikan dan lama investasi) tidak berpengaruh terhadap keputusan investasi seorang investor. Hasil yang sama pada penelitian Pratiwi \& Prijati (2015).

\section{Hubungan Faktor Psikologis Terhadap Keputusan Investasi}

Pengambilan keputusan investasi akan dipengaruhi oleh dua faktor yaitu (1) sejauh mana keputusan investasi dapat memaksimalkan kekayaan dan (2) behavioral motivation (keputusan investasi berdasarkan faktor psikologis investor). Hasil penelitian yang dilakukan oleh Nofsinger (2010) serta Jain dan Mandot (2012) menunjukkan bahwa faktor psikologis seorang investor memiliki pengaruh dalam pengambilan keputusan investasi. 
Jurnal Akuntansi Berkelanjutan Indonesia - Vol. 4, No. 1, Jan 2021 - Wahyuni \& Pramono

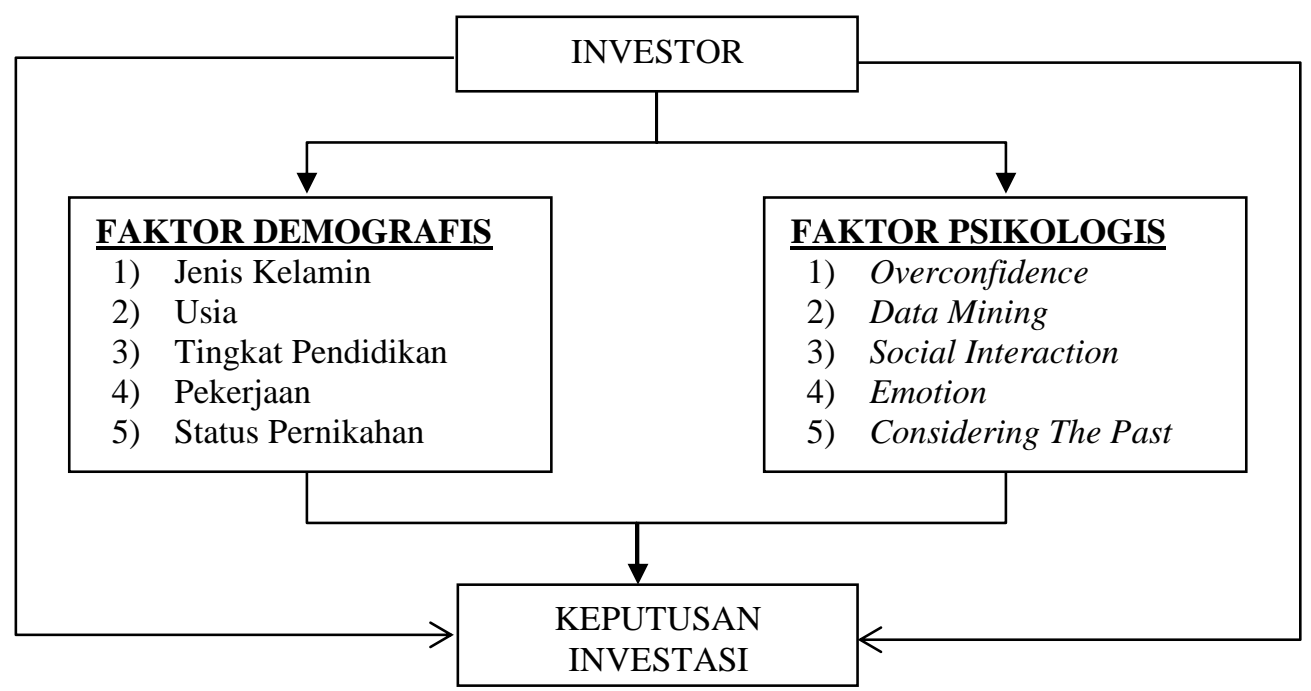

Sumber: Dikembangkan untuk penelitian ini, 2020

\section{Gambar 3. Kerangka Pemikiran Teoritis}

\section{METODE RISET}

Variabel yang digunakan dalam penelitian ini adalah variabel faktor demografis dan variabel faktor psikologis. Indikator untuk mengukur variabel tersebut adalah:

Tabel 1. Indikator dan Definisi Operasional Variabel

VARIABEL Faktor Demografis INDIKATOR Jenis Kelamin

Usia

Tingkat Pendidikan

\section{DEFINISI OPERASIONAL}

Perbedaan biologis pada manusia yang dikenal dengan pria dan wanita (Utami dan Kartini, 2016).

Batasan atau tingkat ukuran hidup yang mempengaruhi kondisi fisik seseorang (Artina dan Cholid, 2018).

Tingkat penguasaan ilmu pengetahuan yang dimiliki seseorang tentang bagaimana kemampuannya dalam memahami suatu hal dengan baik khususnya di bidang akademik (Puspitasari,2014).

Pekerjaan Profesi yang disandang seseorang
dalam melakukan aktivitas yang memberikan hasil baik berupa pengalaman atau materi yang dapat menunjang kehidupannya (Puspitasari,2014).

Status Pernikahan Gelar non - akademis yang disandang oleh orang yang sudah dewasa dan mampu menanggung hidupnya bersama orang lain (Puspitasari,2014).

* Corresponding author's e-mail: asri.nur.wahyuni@gmail.com

http://openjournal.unpam.ac.id/index.php/JABI 


\begin{tabular}{|c|c|c|}
\hline VARIABEL & INDIKATOR & DEFINISI OPERASIONAL \\
\hline \multirow[t]{5}{*}{ Faktor Psikologis } & Overconfidence & $\begin{array}{l}\text { Sifat yang terlalu percaya diri } \\
\text { (Puspitasari,2014). }\end{array}$ \\
\hline & Data Mining & $\begin{array}{l}\text { Proses penggalian data yang } \\
\text { sebelumnya tidak diketahui, informasi } \\
\text { yang valid dan ditindaklanjuti dari } \\
\text { database yang besar dan kemudian } \\
\text { menggunakan informasi tersebut untuk } \\
\text { membuat keputusan bisnis penting } \\
\text { (Gatnar dkk, 2005). }\end{array}$ \\
\hline & Social Interaction & $\begin{array}{l}\text { Bagaimana orang-orang berkomunikasi } \\
\text { dan berbagi informasi yang berkaitan } \\
\text { dengan investasi (Nosfinger, 2010). }\end{array}$ \\
\hline & Emotion & $\begin{array}{lrr}\text { Semakin kompleks } & \text { dan adanya } \\
\text { ketidakpastian dari satu } & \text { situasi, emosi } \\
\text { akan semakin } & \text { mempengaruhi } \\
\text { keputusan untuk } & \text { berinvestasi } \\
\text { (Nosfinger, 2010) } & \end{array}$ \\
\hline & Considering The Past & $\begin{array}{l}\text { Menjadikan kejadian di masa lalu } \\
\text { sebagai dasar evaluasi untuk } \\
\text { menentukan apakah situasi yang } \\
\text { dialami di masa lalu diinginkan } \\
\text { kembali atau dihindari di masa depan } \\
\text { (Nosfinger, 2010) }\end{array}$ \\
\hline \multirow[t]{3}{*}{ Keputusan Investasi } & Return & Keuntungan investasi (Halim, 2015). \\
\hline & Risk & Risiko inbvestasi (Halim, 2015). \\
\hline & Pengambilan Keputusan & $\begin{array}{l}\text { Proses yang digunakan untuk memilih } \\
\text { suatu tindakan sebagai cara pemecahan } \\
\text { masalah (Halim, 2015). }\end{array}$ \\
\hline
\end{tabular}

Sumber: Berbagai Literasi

Data dalam penelitian ini merupakan data primer yang diperoleh dengan menyebarkan kuesioner kepada masyarakat di Indonesia melalui google form. Sampel yang diambil dalam penelitian ini sebanyak 100 responden. Para responden akan mengisi data pribadi yang akan mewakili sebagai data faktor demografi serta menjawab 32 pertanyaan yang terkait faktor psikologis dan pengambilan keputusan investasi dengan mengandung beberapa indikator pada masing-masing pertanyaannya. Untuk masing - masing pertanyaan, jawaban akan dikelompokkan dalam 5 kriteria yaitu: (1) Sangat Tidak Setuju (2) Tidak Setuju (3) Netral (4) Setuju dan (5) Sangat Setuju. Hasil dari kuesioner selanjutnya dianalisis dan dijelaskan secara deskriptif arti dari angka - angka yang tercantum.

Analisis data yang digunakan dalam penelitian ini adalah metode deskriptif, analisis frekuensi, analisis crosstab serta uji chi square. Jenis data dalam penelitian ini adalah data kualitatif yaitu data yang tidak bisa dihitung dalam angka tetapi dapat diukur atau dikategorikan dalam beberapa golongan. Maka pengolahan data menggunakan analisis deskriptif dengan SPSS.

Untuk mengetahui seberapa sering jawaban kelompok responden untuk setiap variabel maka dilakukan analisis frekuensi. Sementara itu, analisis crosstab bertujuan untuk mengetahui ada atau tidaknya hubungan antara faktor demografi dengan faktor psikologis investor dalam pengambilan keputusan investasi. 
Jurnal Akuntansi Berkelanjutan Indonesia - Vol. 4, No. 1, Jan 2021 - Wahyuni \& Pramono

Pengujian hubungan antara faktor demografi dan faktor psikologis terhadap pengambilan keputusan investasi dilakukan dengan uji chi square dengan menentukan kriteria pengujian chi square yaitu jika $\mathrm{p}$-value $<0,05$ maka $\mathrm{H}_{0}$ ditolak dan jika $\mathrm{p}$-value > 0,05 maka $\mathrm{H}_{0}$ diterima.

\section{ANALISIS DATA DAN PEMBAHASAN}

\section{Analisis Frekuensi}

Analisis frekuensi dilakukan untuk mengetahui seberapa sering jawaban kelompok responden untuk setiap variabel. Secara ringkas, hasil analisis frekuensi atas faktor demografi dalam penelitian ini ditunjukkan pada tabel 1 dibawah ini.

Tabel 2. Hasil Analisis Frekuensi Faktor Demografi

\begin{tabular}{|c|c|c|c|}
\hline \multicolumn{2}{|c|}{ Frekuensi Jawaban Responden } & \multirow{2}{*}{$\begin{array}{c}\text { Orang } \\
54\end{array}$} & \multirow{2}{*}{$\begin{array}{c}\text { Persen } \\
54\end{array}$} \\
\hline \multirow{3}{*}{ Jenis Kelamin } & Laki - Laki & & \\
\hline & Perempuan & 46 & 46 \\
\hline & Total & 100 & 100 \\
\hline \multirow{6}{*}{ Usia } & $<20$ tahun & 4 & 4 \\
\hline & $20-30$ tahun & 27 & 27 \\
\hline & $31-40$ tahun & 44 & 44 \\
\hline & $41-50$ tahun & 18 & 18 \\
\hline & $>50$ tahun & 7 & 7 \\
\hline & Total & 100 & 100 \\
\hline \multirow{6}{*}{ Pendidikan } & Doktor (S3) & 3 & 3 \\
\hline & Lainnya ........... & 5 & 5 \\
\hline & Master (S2) & 35 & 35 \\
\hline & Sarjana (S1) & 40 & 40 \\
\hline & SMA & 17 & 17 \\
\hline & Total & 100 & 100 \\
\hline \multirow{4}{*}{ Status Pernikahan } & Belum Menikah & 34 & 34 \\
\hline & Janda / Duda & 1 & 1 \\
\hline & Sudah Menikah & 65 & 65 \\
\hline & Total & 100 & 100 \\
\hline \multirow{8}{*}{ Pekerjaan } & Ibu Rumah Tangga & 5 & 5 \\
\hline & Lainnya....... & 17 & 17 \\
\hline & Mahasiswa & 6 & 6 \\
\hline & Pegawai Swasta & 34 & 34 \\
\hline & PNS & 13 & 13 \\
\hline & Tenaga Pendidik & 17 & 17 \\
\hline & Wiraswasta & 8 & 8 \\
\hline & Total & 100 & 100 \\
\hline
\end{tabular}

Sumber: Data primer yang diolah, 2020.

* Corresponding author's e-mail: asri.nur.wahyuni@gmail.com

http://openjournal.unpam.ac.id/index.php/JABI 
a. Faktor Demografis

Jenis Kelamin responden dalam penelitian ini laki - laki sebesar 54\% dan perempuan sebesar $46 \%$ dengan usia responden terbanyak di rentang $31-40$ tahun sebesar 44\%. Responden dalam penelitian ini memiliki pendidikan terakhir terbanyak di jenjang Sarjana (S1) sebesar $40 \%$ dengan status pernikahan responden terbanyak adalah sudah menikah sebesar $65 \%$. Pekerjaan yang dimiliki responden dalam penelitian ini terbanyak adalah sebagai pegawai swasta sebesar $34 \%$.

b. Faktor Psikologi

Pada indikator overconfidence di analisis frekuensi menunjukkan sebanyak 38 $\%$ responden setuju memiliki keyakinan akan keuntungan yang didapat dari investasi yang dijalaninya. Sementara responden akan bersikap netral atas keyakinan akan kemampuan mereka mengenai investasi yang dimiliki lebih baik dari investor lain sebanyak $37 \%$. Responden yang setuju akan pengetahuan mengenai investasi yang dimiliki mereka sebanyak $37 \%$ dan $41 \%$ responden sangat setuju akan keyakinan atas pemilihan investasi mereka.

Faktor psikologis berupa data mining dalam analisis frekuensi yaitu sebanyak $47 \%$ responden sangat setuju bahwa mereka tertarik melakukan investasi karena melihat manfaat yang dapat diperoleh dari kegiatan investasi Responden yang setuju untuk melakukan investasi berdasarkan data dari tahun ke tahun produk investasi mengalami perkembangan sebanyak $40 \%$. Responden setuju bahwa melakukan investasi berdasarkan pertimbangan atas track record produk investasi sebanyak $44 \%$ dan 51\% responden sangat setuju jika sebelum melakukan investasi mereka akan membandingkan berbagai macam produk investasi.

Dalam social interaction, hasil analisis frekuensinya menunjukkan hasil sebanyak $33 \%$ responden tidak setuju jika mereka membeli / menjual produk investasi semata - mata karena saran dari teman/kerabat/informasi di media massa. Sebanyak $32 \%$ responden bersikap netral bahwa mereka berinvestasi atas rekomendasi keluarga dan teman yang sudah melakukan investasi terlebih dahulu. Sebanyak $29 \%$ responden setuju bahwa mereka akan selalu menanyakan kepada keluarga dan teman tentang keuntungan yang akan diperoleh saat memilih suatu investasi. Sebanyak $30 \%$ responden bersikap netral atas keyakin terhadap investasi yang disarankan oleh teman yang mereka percaya

Dari sisi emosi responden diketahui Sebanyak $33 \%$ responden setuju bahwa mereka dapat melakukan investasi lebih tepat saat dala kondisi good mood. Sebanyak $41 \%$ responden bersikap netral mereka sering merasa cemas saat menghadapi ketidakpastian berinvestasi.Sebanyak $32 \%$ responden bersikap netral saat mereka berinvestasi merasakan ketakutan dalam mengambil risiko jika produk investasi tersebut tidak menguntungkan.Sebanyak $39 \%$ responden tidak merasa menyesal telah melakukan investasi.

Yang terakhir dalam faktor psikologis adalah considiring the past. Sebanyak $43 \%$ responden sangat setuju untuk menggunakan pengalaman dan memori atas kejadian masa lalu sebagai dasar untuk berinvestasi yang lebih baik.

* Corresponding author's e-mail: asri.nur.wahyuni@gmail.com

http://openjournal.unpam.ac.id/index.php/JABI 
Sebanyak $39 \%$ responden sangat setuju bahwa mereka lebih mengingat kejadian yang mengakibatkan mereka mendapatkan keuntungan atau kerugian dalam berinvestasi . Sebanyak $39 \%$ responden merasa lebih merasa tenang dalam hal finansial ketika memiliki investasi.Sebanyak $28 \%$ responden tidak setuju jika pengalaman buruk yang mereka alami saat berinvestasi menjadikan mereka tidak berani untuk berinvestasi kembali.

c. Pengambilan Keputusan Investasi

Pengambilan keputusan investasi diambil dari 3 indikator yaitu return (keuntungan investasi), risk (risiko investasi) dan keputusan investasi. Analisis frekuensi atas variabel pengambilan keputusan dari sisi return (keuntungan investasi) menunjukkan hasil sebanyak $40 \%$ responden sangat setuju untuk mengutamakan keuntungan investasi dari produk investasi yang dipilih dan 44 $\%$ responden sangat setuju bahwa return menjadi satu hal yang sangat mendasar dalam mengambil keputusan investasi. Diketahui pula sebanyak 52 $\%$ responden yang sangat setuju untuk mengetahui keuntungan investasi yang akan diterima dengan berusaha mencari informasi penting dari berbagai pihak. Responden sangat setuju untuk selalu memilih investasi yang memiliki kemungkinan return tinggi sebanyak $37 \%$.

Dari sisi risk (risiko investasi), sebanyak $56 \%$ responden sangat setuju bahwa sebelum menentukan pilihan investasi mereka akan mempelajari terlebih dahulu risiko apa saja yang akan diterima. Sebanyak $46 \%$ responden sangat setuju untuk membuat portofolio investasi sebagai cara termudah dalam mengurangi risiko investasi. Sebanyak $37 \%$ responden setuju bahwa risiko tidak selalu mengarah pada kerugian. Responden yang bersikap netral pada saat kondisi keuangan yang tidak stabil tidak mengecilkan minat mereka untuk berinvestasi sebanyak $33 \%$.

Hasil analisis frekuensi atas keputusan investasi yaitu Sebanyak $43 \%$ responden sangat setuju selalu menyisihkan uang untuk berinvestasi sebelum membelanjakan uang bulanan mereka. Sebanyak $36 \%$ responden sangat setuju menggunakan sebagian pendapatan bulanan untuk investasi. Sebanyak $55 \%$ responden sangat setuju untuk melakukan investasi dengan pertimbangan. Responden yang sangat setuju bahwa mereka berinvestasi guna memenuhi kebutuhan keluarga di masa depan sebanyak $58 \%$.

\section{Pengujian Faktor Demografi Terhadap Keputusan Investasi}

Chi Square test dilakukan untuk mengetahui pengaruh faktor demografi responden terhadap keputusan investasi. Chi Square test digunakan untuk menguji apakah variabel $\mathrm{X}$ dan variabel $\mathrm{Y}$ terdapat hubungan dengan melihat nilai signifikansinya (Ghozali, 2012). Faktor demografi responden yang diuji terdiri dari jenis kelamin, usia, pendidikan, status pernikahan dan pekerjaan. Hasil pengujiannya dapat dilihat pada tabel 3 dibawah ini:

Tabel 3. Chi - Square Test Faktor Demografi - Keputusan Investasi

\begin{tabular}{lcc}
\hline \multicolumn{1}{c}{ Indikator } & Chi Square & Sig \\
\hline Jenis Kelamin & $4.351^{\mathrm{a}}$ & 0.114 \\
Usia & $17.120^{\mathrm{a}}$ & 0.029 \\
\hline
\end{tabular}

* Corresponding author's e-mail: asri.nur.wahyuni@gmail.com

http://openjournal.unpam.ac.id/index.php/JABI 
Jurnal Akuntansi Berkelanjutan Indonesia - Vol. 4, No. 1, Jan 2021 - Wahyuni \&

Pramono

\begin{tabular}{lcc}
\hline Pendidikan & $30.179^{\mathrm{a}}$ & 0.000 \\
Status Pernikahan & $4.892^{\mathrm{a}}$ & 0.299 \\
Pekerjaan & $20.888^{\mathrm{a}}$ & 0.052 \\
\hline
\end{tabular}

Sumber : Data primer yang diolah, 2020.

Dari tabel di atas, pengujian untuk pengaruh jenis kelamin terhadap keputusan investasi menunjukkan nilai signifikansi $0,114>0,05$. Hal ini berarti bahwa jenis kelamin responden tidak berpengaruh terhadap pengambilan keputusan investasi. Pada faktor demografi kedua hasil pengujiannya menunjukkan nilai signifikansi sebesar $0,029<0,05$. Hal ini berarti usia memiliki pengaruh saat pengambilan keputusan investasi. Pengujian untuk pendidikan responden terhadap keputusan investasi menunjukkan nilai signifikansi $0,000<0,05$. Hasil ini memiliki arti bahwa pendidikan responden berpengaruh terhadap pengambilan keputusan investasi. Pengujian atas faktor demografi berupa status pernikahan terhadap keputusan menunjukkan nilai signifikansi 0,299 > 0,05. Hal ini berarti bahwa status pernikahan tidak berpengaruh terhadap pengambilan keputusan investasi. Faktor demografi terakhir yang diuji adalah pekerjaan responden. Nilai signifikansinya $0,0502>0,02$. Hal ini menunjukkan bahwa pekerjaan tidak berpengaruh terhadap pengambilan keputusan investasi.

\section{Pengujian Faktor Psikologi Terhadap Keputusan Investasi}

Untuk mengetahui ada atau tidaknya hubungan antara faktor psikologis investor dalam pengambilan keputusan investasi dilakukan dengan analisis crosstab. Faktor psikologis yang diuji adalah overconfidence, data mining, social interaction, emotion dan considering the past dengan hasil yang ditunjukkan pada tabel 4.

Tabel 4. Chi - Square Test Faktor Psikologi - Keputusan Investasi Chi-Square Tests

\begin{tabular}{|l|c|c|c|}
\hline & Value & Df & Asymp. Sig. (2-sided) \\
\hline Pearson Chi-Square & $17.870^{\mathrm{a}}$ & 4 & 0.001 \\
Likelihood Ratio & 16.219 & 4 & 0.003 \\
Linear-by-Linear & 13.246 & 1 & 0.000 \\
Association & 100 & & \\
N of Valid Cases & & \\
\hline
\end{tabular}

a. 4 cells $(44.4 \%)$ have expected count less than 5 . The minimum expected count is 1.10 .

Sumber : SPSS, 2020

Berdasarkan hasil Chi - Square Test di atas menunjukkan bahwa nilai sebesar 17,870 dengan probabilitas signifikansi 0,001. Hal ini menunjukkan bahwa faktor psikologi yang terdiri dari overconfidence, data mining, social interaction, emotion dan considering the past memiliki pengaruh terhadap keputusan investasi.

* Corresponding author's e-mail: asri.nur.wahyuni@gmail.com

http://openjournal.unpam.ac.id/index.php/JABI 
Jurnal Akuntansi Berkelanjutan Indonesia - Vol. 4, No. 1, Jan 2021 - Wahyuni \& Pramono

Tabel 5. Uji Crosstab Faktor Psikologi - Keputusan Investasi Tot_Psiko* Tot_TPKI Crosstabulation

\begin{tabular}{|c|c|c|c|c|c|c|}
\hline & \multicolumn{3}{|c|}{ Tot_TPKI } & \multirow{2}{*}{ Total } \\
\hline & & & Rendah & Sedang & Tinggi & \\
\hline \multirow{9}{*}{ Tot_Psiko } & Rendah & Count & 9 & 9 & 1 & 19 \\
\hline & & $\%$ within Tot_TPKI & $50.0 \%$ & $12.7 \%$ & $9.1 \%$ & $19.0 \%$ \\
\hline & & $\%$ of Total & $9.0 \%$ & $9.0 \%$ & $1.0 \%$ & $19.0 \%$ \\
\hline & Sedang & Count & 9 & 55 & 7 & 71 \\
\hline & & $\%$ within Tot_TPKI & $50.0 \%$ & $77.5 \%$ & $63.6 \%$ & $71.0 \%$ \\
\hline & & $\%$ of Total & $9.0 \%$ & $55.0 \%$ & $7.0 \%$ & $71.0 \%$ \\
\hline & Tinggi & Count & 0 & 7 & 3 & 10 \\
\hline & & $\%$ within Tot_TPKI & $0.0 \%$ & $9.9 \%$ & $27.3 \%$ & $10.0 \%$ \\
\hline & & $\%$ of Total & $0.0 \%$ & $7.0 \%$ & $3.0 \%$ & $10.0 \%$ \\
\hline & & Count & 18 & 71 & 11 & 100 \\
\hline \multirow{2}{*}{ Tota } & & $\%$ within Tot_TPKI & $100.0 \%$ & $100.0 \%$ & $100.0 \%$ & $100.0 \%$ \\
\hline & & $\%$ of Total & $18.0 \%$ & $71.0 \%$ & $11.0 \%$ & $100.0 \%$ \\
\hline
\end{tabular}

Sumber : SPSS,2020

Berdasarkan tabel 5 diketahui bahwa faktor psikologi secara keseluruhan mempengaruhi pengambilan keputusan investasi yang rendah sebesar $18 \%$. Pengambilan keputusan investasi tertinggi berada pada tingkat sedang dipengaruhi oleh faktor psikologi sebesar $71 \%$ dan pada tingkat tinggi sebesar $11 \%$.

Pengujian Faktor Demografi dan Faktor Psikologi Secara Bersama - Sama Terhadap Keputusan Investasi

Tabel 6. Uji F

\begin{tabular}{|c|c|c|c|c|c|c|}
\hline \multicolumn{7}{|c|}{ ANOVA $^{a}$} \\
\hline & Model & Sum of Squares & Df & Mean Square & $\mathrm{F}$ & Sig. \\
\hline \multirow{3}{*}{1} & Regression & 1075.792 & 6 & 179.299 & 5.987 & $0.000^{\mathrm{b}}$ \\
\hline & Residual & 2785.208 & 93 & 29.948 & & \\
\hline & Total & 3861.000 & 99 & & & \\
\hline \multicolumn{7}{|c|}{ a. Dependent Variable: Pengambilan Keputusan } \\
\hline \multicolumn{7}{|c|}{ b. Predictors: (Constant), Tot_Psiko, Pendidikan, JK, SP, Pekerjaan, Usia } \\
\hline
\end{tabular}

Berdasarkan hasil uji $\mathrm{F}$ di atas menunjukkan bahwa nilai signifikansi 0,001 $<0,05$ yang berarti bahwa faktor demografi dan faktor psikologis secara bersamasama mempengaruhi pengambilan keputusan investasi dan hipotesis ketiga dapat diterima.

Faktor demografi pada hasil Chi - Square Test pada tabel 3 di atas menunjukkan hasil bahwa jenis kelamin, status pernikahan dan pekerjaan tidak berpengaruh terhadap pengambilan keputusan investasi. Hal ini disebabkan karena mereka menganggap bahwa risiko memang ada dan harus dihadapi pada saat mengambil keputusan untuk berinvestasi. Hasil penelitian ini mendukung hasil

* Corresponding author's e-mail: asri.nur.wahyuni@gmail.com

http://openjournal.unpam.ac.id/index.php/JABI 
yang diperoleh dari penelitian yang telah dilakukan oleh Utami dan Kartini (2016) serta Pratiwi dam Prijati (2015).

Sementara faktor demografi usia dan pendidikan menunjukkan hasil memiliki pengaruh terhadap pengambilan keputusan investasi. Pertimbangan masa tua bagi investor menjadikan mereka lebih berhati - hati dan tidak menginginkan pengeluaran yang berlebihan yang akan menjadikan beban bagi mereka. Sehingga semakin matang usia seorang investor maka semakin bijak mereka untuk mengambil keputusan berinvestasi. Hasil penelitian ini sesuai dengan penelitian yang dilakukan oleh Christanti dan Mahastanti (2011). Artina dan Idham (2018), Iswantoro dan Anastasia (2013), Harli dkk (2015), Arafia (2011) serta Pradhan dam Kasilingam (2015).

Begitu pula pada faktor tingkat pendidikan. Semakin tinggi tingkat pendidikan investor semakin banyak pula faktor - faktor yang akan dipertimbangkan sehingga keputusan untuk berinvestasi dilakukan dengan lebih teliti. Hal ini didasarkan pada tingkat pendidikan yang semakin tinggi menjadikan pengetahuan mereka akan investasi pun semakin banyak pula. Hasil penelitian ini mendukung hasil penelitian yang telah dilakukan oleh Artina dan Idham (2018). Bhandari dan Deaves (2006), Jamshidinavid e al (2012) serta Lin (2011).

Hasil ini diperkuat dengan hasil uji crosstab faktor demografi dari segi jenis kelamin (tabel 7), usia (tabel 8), pendidikan (tabel 9), status pernikahan (tabel 10) dan pekerjaan (tabel 11) menunjukkan bahwa investor cenderung bersifat risk neutral di mana mereka menganggap bahwa risiko adalah hal yang harus dihadapi. Namun hasil yang sedikit berbeda ditunjukkan pada faktor demografi pendidikan. Responden dengan tingkat pendidikan Doktor (S3) cenderung lebih berani mengambil risiko daripada responden di jenjang pendidikan yang lainnya. Hal ini dikarenakan tingkat pertimbangan dan pengetahuan investor yang semakin tinggi akan menjadikan mereka berani untuk mengambil risiko yang lebih tinggi lagi.

Tabel 7. Uji Crosstab Faktor Demografi (Jenis Kelamin)-Keputusan Investasi Crosstab

\begin{tabular}{|c|c|c|c|c|c|c|}
\hline & \multicolumn{3}{|c|}{ Tot_TPKI } & \multirow[t]{2}{*}{ Total } \\
\hline & & & Rendah & Sedang & Tinggi & \\
\hline \multirow{7}{*}{ JK } & \multirow[t]{2}{*}{ Laki - Laki } & Count & 12 & 39 & 3 & 54 \\
\hline & & $\%$ within Tot_TPKI & $66.7 \%$ & $54.9 \%$ & $27.3 \%$ & $54.0 \%$ \\
\hline & \multirow{5}{*}{ Perempuan } & $\%$ of Total & $12.0 \%$ & $39.0 \%$ & $3.0 \%$ & $54.0 \%$ \\
\hline & & Count & 6 & 32 & 8 & 46 \\
\hline & & $\%$ within Tot_TPKI & $33.3 \%$ & $45.1 \%$ & $72.7 \%$ & $46.0 \%$ \\
\hline & & $\%$ of Total & $6.0 \%$ & $32.0 \%$ & $8.0 \%$ & $46.0 \%$ \\
\hline & & Count & 18 & 71 & 11 & 100 \\
\hline \multirow[t]{2}{*}{ Total } & & $\%$ within Tot_TPKI & $100.0 \%$ & $100.0 \%$ & $100.0 \%$ & $100.0 \%$ \\
\hline & & $\%$ of Total & $18.0 \%$ & $71.0 \%$ & $11.0 \%$ & $100.0 \%$ \\
\hline
\end{tabular}

Sumber : SPSS,2020 
Jurnal Akuntansi Berkelanjutan Indonesia - Vol. 4, No. 1, Jan 2021 - Wahyuni \& Pramono

Tabel 8. Uji Crosstab Faktor Demografi (Usia) - Keputusan Investasi Crosstab

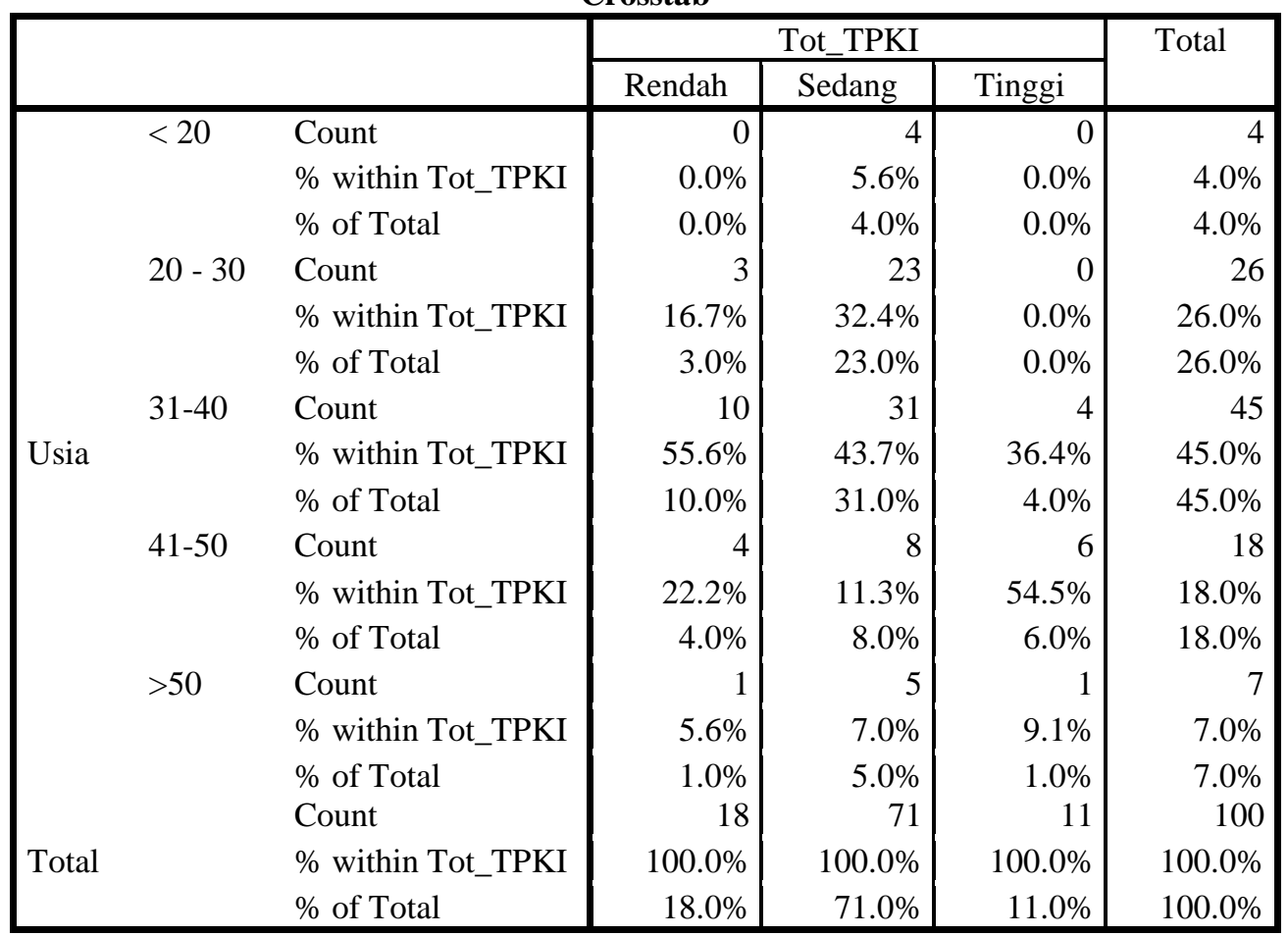

Sumber : SPSS,2020

Tabel 9. Uji Crosstab Faktor Demografi (Pendidikan)-Keputusan Investasi

\begin{tabular}{|c|c|c|c|c|c|c|}
\hline & & & \multicolumn{3}{|c|}{ Tot_TPKI } & \multirow[t]{2}{*}{ Total } \\
\hline & & & Rendah & Sedang & Tinggi & \\
\hline & \multirow[t]{3}{*}{ SMA } & Count & 2 & 15 & $\overline{0}$ & 17 \\
\hline & & $\%$ within Tot_TPKI & $11.1 \%$ & $21.1 \%$ & $0.0 \%$ & $17.0 \%$ \\
\hline & & $\%$ of Total & $2.0 \%$ & $15.0 \%$ & $0.0 \%$ & $17.0 \%$ \\
\hline & \multirow[t]{3}{*}{ Sarjana (S1) } & Count & 8 & 29 & 3 & 40 \\
\hline & & $\%$ within Tot_TPKI & $44.4 \%$ & $40.8 \%$ & $27.3 \%$ & $40.0 \%$ \\
\hline & & $\%$ of Total & $8.0 \%$ & $29.0 \%$ & $3.0 \%$ & $40.0 \%$ \\
\hline & Master (S2) & Count & 6 & 25 & 4 & 35 \\
\hline \multirow[t]{9}{*}{ Pendidikan } & & $\%$ within Tot_TPKI & $33.3 \%$ & $35.2 \%$ & $36.4 \%$ & $35.0 \%$ \\
\hline & & $\%$ of Total & $6.0 \%$ & $25.0 \%$ & $4.0 \%$ & $35.0 \%$ \\
\hline & Doktor (S3) & Count & 0 & 0 & 3 & \\
\hline & & $\%$ within Tot_TPKI & $0.0 \%$ & $0.0 \%$ & $27.3 \%$ & $3.0 \%$ \\
\hline & & $\%$ of Total & $0.0 \%$ & $0.0 \%$ & $3.0 \%$ & $3.0 \%$ \\
\hline & Lainnya & Count & 2 & 2 & 1 & \\
\hline & & $\%$ within Tot_TPKI & $11.1 \%$ & $2.8 \%$ & $9.1 \%$ & $5.0 \%$ \\
\hline & & $\%$ of Total & $2.0 \%$ & $2.0 \%$ & $1.0 \%$ & $5.0 \%$ \\
\hline & & Count & 18 & 71 & 11 & 10 \\
\hline \multirow[t]{2}{*}{ Total } & & $\%$ within Tot_TPKI & $100.0 \%$ & $100.0 \%$ & $100.0 \%$ & $100.0 \%$ \\
\hline & & $\%$ of Total & $18.0 \%$ & $71.0 \%$ & $11.0 \%$ & $100.0^{c}$ \\
\hline
\end{tabular}

Sumber : SPSS,2020

* Corresponding author's e-mail: asri.nur.wahyuni@gmail.com

http://openjournal.unpam.ac.id/index.php/JABI 
Jurnal Akuntansi Berkelanjutan Indonesia - Vol. 4, No. 1, Jan 2021 - Wahyuni \& Pramono

Tabel 10. Uji Crosstab Faktor Demografi (Status Pernikahan)-Keputusan Investasi Crosstab

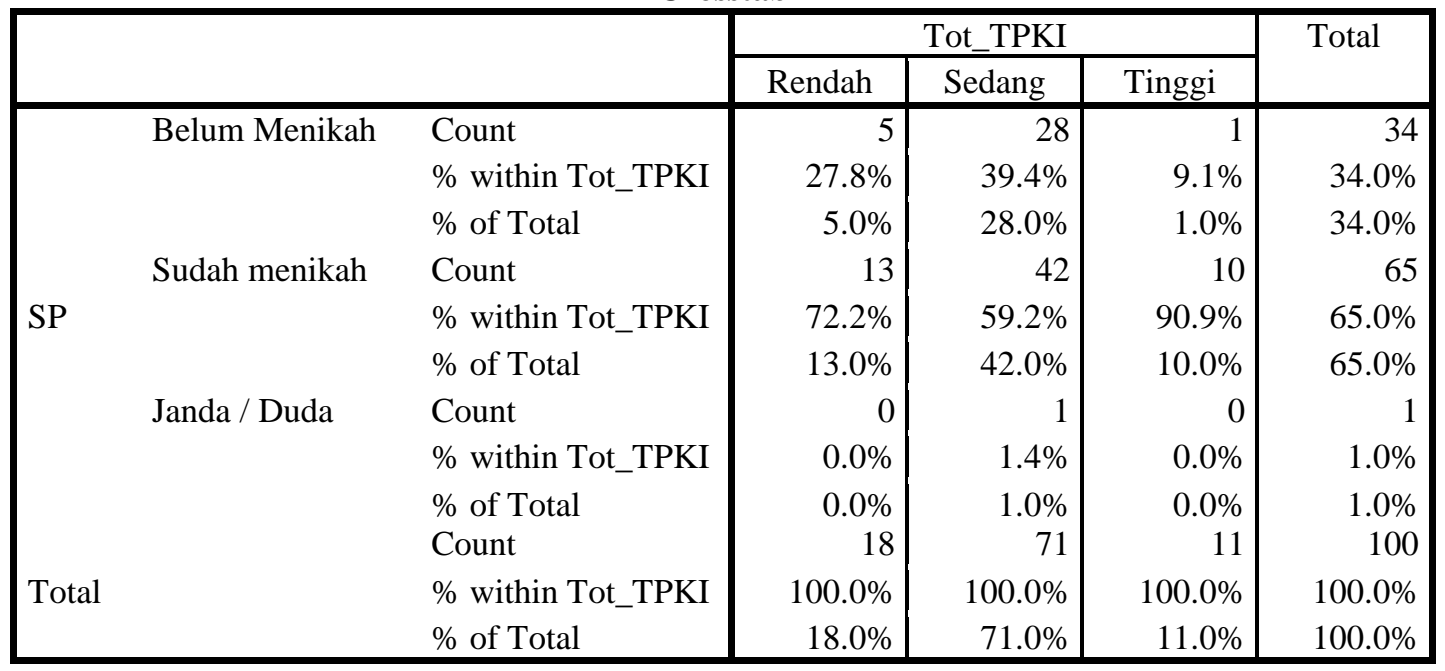

Sumber : SPSS,2020

Tabel 11. Uji Crosstab Faktor Demografi (Pekerjaan)-Keputusan Investasi Crosstab

\begin{tabular}{|c|c|c|c|c|c|c|}
\hline & \multicolumn{3}{|c|}{ Tot_TPKI } & \multirow[t]{2}{*}{ Total } \\
\hline & & & Rendah & Sedang & Tinggi & \\
\hline \multirow{3}{*}{\multicolumn{2}{|c|}{ Mahasiswa }} & $\overline{\text { Count }}$ & $\overline{1}$ & 5 & $\overline{0}$ & 6 \\
\hline & & $\%$ within Tot_TPKI & $5.6 \%$ & $7.0 \%$ & $0.0 \%$ & $6.0 \%$ \\
\hline & & $\%$ of Total & $1.0 \%$ & $5.0 \%$ & $0.0 \%$ & $6.0 \%$ \\
\hline \multirow{3}{*}{\multicolumn{2}{|c|}{ Tenaga Pendidik }} & Count & 0 & 11 & 6 & 17 \\
\hline & & $\%$ within Tot_TPKI & $0.0 \%$ & $15.5 \%$ & $54.5 \%$ & $17.0 \%$ \\
\hline & & $\%$ of Total & $0.0 \%$ & $11.0 \%$ & $6.0 \%$ & $17.0 \%$ \\
\hline \multirow{3}{*}{\multicolumn{2}{|c|}{ PNS }} & Count & 4 & 9 & 0 & 13 \\
\hline & & $\%$ within Tot_TPKI & $22.2 \%$ & $12.7 \%$ & $0.0 \%$ & $13.0 \%$ \\
\hline & & $\%$ of Total & $4.0 \%$ & $9.0 \%$ & $0.0 \%$ & $13.0 \%$ \\
\hline & Ibu Rumah Tangga & Count & 1 & 3 & 1 & 5 \\
\hline \multirow[t]{12}{*}{ Pekerjaan } & & $\%$ within Tot_TPKI & $5.6 \%$ & $4.2 \%$ & $9.1 \%$ & $5.0 \%$ \\
\hline & & $\%$ of Total & $1.0 \%$ & $3.0 \%$ & $1.0 \%$ & $5.0 \%$ \\
\hline & Pegawai Swasta & Count & 8 & 23 & 3 & 34 \\
\hline & & $\%$ within Tot_TPKI & $44.4 \%$ & $32.4 \%$ & $27.3 \%$ & $34.0 \%$ \\
\hline & & $\%$ of Total & $8.0 \%$ & $23.0 \%$ & $3.0 \%$ & $34.0 \%$ \\
\hline & Wiraswasta & Count & 0 & 8 & 0 & 8 \\
\hline & & $\%$ within Tot_TPKI & $0.0 \%$ & $11.3 \%$ & $0.0 \%$ & $8.0 \%$ \\
\hline & & $\%$ of Total & $0.0 \%$ & $8.0 \%$ & $0.0 \%$ & $8.0 \%$ \\
\hline & Lainnya & Count & 4 & 12 & 1 & 17 \\
\hline & & $\%$ within Tot_TPKI & $22.2 \%$ & $16.9 \%$ & $9.1 \%$ & $17.0 \%$ \\
\hline & & $\%$ of Total & $4.0 \%$ & $12.0 \%$ & $1.0 \%$ & $17.0 \%$ \\
\hline & & Count & 18 & 71 & 11 & 100 \\
\hline \multirow[t]{2}{*}{ Total } & & $\%$ within Tot_TPKI & $100.0 \%$ & $100.0 \%$ & $100.0 \%$ & $100.0 \%$ \\
\hline & & $\%$ of Total & $18.0 \%$ & $71.0 \%$ & $11.0 \%$ & $100.0 \%$ \\
\hline
\end{tabular}

Sumber : SPSS,2020

* Corresponding author's e-mail: asri.nur.wahyuni@gmail.com http://openjournal.unpam.ac.id/index.php/JABI 
Berdasarkan hasil tabel 4 diketahui bahwa responden lebih memilih untuk menjadi risk neutral di mana responden menganggap bahwa risiko adalah hal yang wajar. Secara psikologi baik pada faktor overconfidence, data mining, social interaction, emotion maupun considering the past secara keseluruhan menjadikan risiko adalah hal yang wajar untuk dihadapi saat berinvestasi. Hasil penelitian ini sesuai dengan hasil penelitian yang telah dilakukan oleh Jain dan Mandot (2012) serta Gatnar, Rozmus dan Dorota (2005).

Sehingga dapat diambil kesimpulan bahwa baik faktor demografi maupun faktor psikologi seorang investor memiliki pengaruh terhadap pengambilan keputusan investasi, baik secara parsial maupun secara bersama - sama.

\section{KESIMPULAN DAN SARAN}

Usia dan pendidikan sebagai faktor demografi memiliki pengaruh terhadap keputusan investasi. Sementara itu, hasil yang berbeda ditunjukkan pada faktor demografi yang lain dalam penelitian ini yaitu jenis kelamin, status pernikahan dan pekerjaan tidak memiliki pengaruh pada keputusan investasi. Hasil lainnya dalam penelitian ini menunjukkan bahwa faktor psikologi yang terdiri dari overconfidence, data mining, social interaction, emotion dan considering the past berpengaruh terhadap keputusan investasi. Faktor demografi dengan faktor psikologis dalam penelitian ini secara bersama - sama memiliki pengaruh terhadap keputusan investasi.

Keterbatasan dalam penelitian ini terdapat pada faktor yang mempengaruhi keputusan investasi yang tidak merujuk secara detail pada jenis instrumen investasi yang ada, sehingga diharapkan pada penelitian selanjutnya dapat memasukkan unsur jenis instrumen investasi.

\section{DAFTAR PUSTAKA}

Andrew, Vincentius \& Linawati, Nanik. (2014). Hubungan Faktor Demografi Dan Pengetahuan Keuangan Dengan Perilaku Keuangan Karyawan Swasta Di Surabaya. FINESTA, Vol. 2, No. 2, 35-39.

Arafia, S.E. (2011). Perbedaan Perilaku Konsumtif pada Pria Kelompok Usia Remaja, Dewasa Awal, dan Dewasa Madya di Sinoman, Salatiga.Universitas Kristen Satya Wacana, Salatiga.

Artina, N., \& Cholid, I. (2018). Pengaruh Tingkat Literasi Keuangan Dan Faktor Demografi Terhadap Pengambilan Keputusan Investasi (Studi Kasus Pegawai Kantor Badan Kepegawaian Daerah Sumatera Selatan). Jurnal Keuangan Dan Bisnis, (Maret), 84-99.

Bhandari, G. R. \& Deaves. (2006). "The Demographics of Overconfidence". The Journal of Behavioral Finance, Vol.7, Pp. 5-11.

* Corresponding author's e-mail: asri.nur.wahyuni@gmail.com

http://openjournal.unpam.ac.id/index.php/JABI 
Jurnal Akuntansi Berkelanjutan Indonesia - Vol. 4, No. 1, Jan 2021 - Wahyuni \&

Pramono

Christanti, Natalia dan Mahastanti, Linda Ariany. (2011). "Faktor - Faktor Yang Dipertimbangkan Investor Dalam Melakukan Investasi. Jurnal Manajemen Teori dan Terapan Tahun 4 No 3.

Ghozali, Imam. (2012). Analisis Multivariate Dengan aplikasi IBM SPSS. Semarang : Badan Penerbit Universitas Diponegoro.

Halim, Abdul. (2015). Analisis Investasi Di Aset Keuangan. Jakarta. Mitra Wacana Media.

Harli, Felicia Claresta, dkk (2015). "Pengaruh Financial Literacy dan Faktor Sosiodemografi Terhadap Perilaku Konsumtif”. Finesta. Vol.3 No.1 5862.

Iswantoro dan Anastasia (2013). Hubungan Demografi, Anggota Keluarga dan Situasi dalam Pengambilan Keputusan Pendanaan Pembelian Rumah Tinggal Surabaya, Jurnal Finesta, Vol. 1 No. 2 124-129.

Jain, D dan Mandodt E. (2012). "Impact of Demographic Factors on Investors in Rajasthan.: Journal of Arts, Science \& Commerce. Vol. 3 Issue2 (3).

Jamil, Syed Ahsan \& Khan, Khaliquzzaman. (2016). Does Gender Difference Impact Investment Decisions? Evidence From Oman. International. Journal Of Economics And Financial, Issues 6(2), 456-460.

Lin, H-W. (2011). Elucidating The Influence of Demographics and Psychological Traits On Investment Biases. World Academy of Science, Engineering and Technology Vol. 5.

Loke, Yiing-Jia. (2017). The Influence Of Socio-Demographic And Financial Knowledge Factors On Financial Management Practices Of Malaysians. International Journal Of Business And Society, Vol. 18, No. 1, 33-50

Lutfi. (2010). The Relationship Between Demographic Factors and Investment Decision In Surabaya. Journal of Economics, Business and Accountancy Ventura Vol. 13 No. 3 Desember. Hal. 213 - 224.

Nosfinger, J.R. (2010). The Psychology of Investig (Fourth Edition). Boston : Prentice Hall.

Pradhan, Subhendu Kumar dan Kasilingam, R. (2015). Corporate Action And Investment Decision: A Study Based On Demographic Characters Of Investors. Bi-Annual Journal Of Asian School Of Business Management, Vol. 8, Issue 1.

Pratiwi, Indah. (2015). Pengaruh Faktor Demografi Terhadap Jenis Investasi Dan Perilaku Investor Pasar Modal Surabaya.Jurnal Ilmu dan Riset Manajemen Volume 4, Nomor 7, Juli 2015.

Puspitasari, P. N. (2014). Pengaruh Faktor Demografi Dan Faktor Psikologis Terhadap Pengambilan Keputusan Investasi Pada Reksadana. Surabaya.

Rizkiana, Yashica Putri \& Kartini. (2017). Analisis Tingkat Financial Literacy Dan Financial Behavioral Mahasiswa S1 Fakultas Ekonmi Universitas Islam

* Corresponding author's e-mail: asri.nur.wahyuni@gmail.com

http://openjournal.unpam.ac.id/index.php/JABI 
Jurnal Akuntansi Berkelanjutan Indonesia - Vol. 4, No. 1, Jan 2021 - Wahyuni \& Pramono

Indonesia, Vol. 7, No 1.

Utami, L. D., \& Kartini. (2016). Faktor Demografis , Personality Traits , dan Overconfidence (Survey terhadap Investor Saham di Yogyakarta). Jurnal Siasat Bisnis, 20(2), 181-196.

Widayat. (2010). Penentu Perilaku Berinvestasi. Ekonomika - Bisnis Vol. 01 No. 02 Hal. 111 - 128. 